\title{
'Ghost nutrients' from fish farms are transferred up the food web by phytoplankton grazers
}

\author{
Paraskevi Pitta ${ }^{1}$, Manolis Tsapakis ${ }^{1}$, Eugenia T. Apostolaki ${ }^{1}$, Tatiana Tsagaraki ${ }^{1}$, \\ Marianne Holmer ${ }^{2}$, Ioannis Karakassis ${ }^{3, *}$ \\ ${ }^{1}$ Hellenic Centre for Marine Research, Institute of Oceanography, PO Box 2214, 71003 Heraklion, Crete, Greece \\ ${ }^{2}$ Institute of Biology, SDU-Odense University, Campusvej 55, 5230 Odense M, Denmark \\ ${ }^{3}$ Marine Ecology Laboratory, Department of Biology, University of Crete, PO Box 2208, 71409 Heraklion, Crete, Greece
}

\begin{abstract}
Several studies have failed to detect significant changes in chl a content of the water column in the vicinity of fish farms despite the large amount of nutrient wastes discharged into the marine environment. To trace the fate of these disappearing (or 'ghost') nutrients, experiments using dialysis bags deployed in situ along gradients of nutrient enrichment (at different distances from cage fish farms) were carried out at 2 coastal locations in the eastern Mediterranean. The productivity of the water column decreased with distance from the nutrient discharge point, as indicated by the chl a content found in the dialysis bags. However, comparison of the results from bioassays with and without grazer exclusion showed that grazing plays a key role in regulating phytoplankton biomass, keeping chl a at very low levels and effectively transferring nutrients up the food web. The fact that this type of response was found in otherwise oligotrophic conditions is probably due to the structure of the phytoplankton community in such areas, which is based on small cellsize primary producers that can be easily grazed on by planktonic ciliates.
\end{abstract}

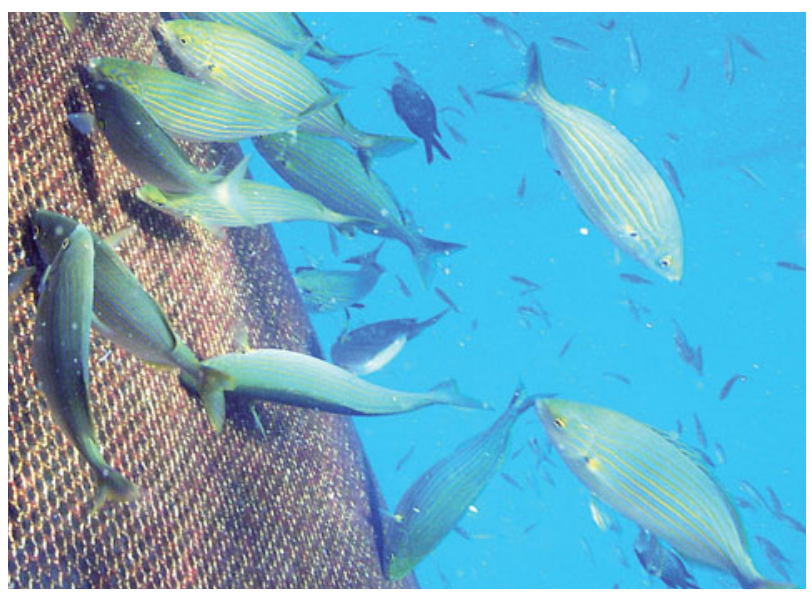

Microplankton grazers prevent eutrophication in the vicinity of fish farms by transferring nutrients up the food web, ultimately to wild fishes.

Photo: Marianne Holmer

KEY WORDS: Phytoplankton $\cdot$ Ciliates $\cdot$ Mariculture $\cdot$ Fish farms $\cdot$ Nutrient loading $\cdot$ Dialysis bags $\cdot$ Eutrophication Resale or republication not permitted without written consent of the publisher

\section{INTRODUCTION}

The Mediterranean is the largest oligotrophic water body on Earth (Krom et al. 2005) and, unlike most marine areas, it is at least in part P-limited (Krom et al. 1991). It is also unusual in that it has a high N:P ratio (Krom et al. 1991), which causes it to be P-limited in winter, while becoming $\mathrm{N}$ and $\mathrm{P}$ co-limited in summer (Thingstad et al. 2005). A recent Lagrangian experi- ment in the eastern Mediterranean (Thingstad et al. 2005) showed no increase in primary production or chl a content after an episodic P-addition. This was interpreted as being due to rapid grazing of the increased microbial production. In a series of investigations on the water column in the vicinity of fish farms adjacent to the Mediterranean coast, there was little observed increase in chl a content (Pitta et al. 1999, 2005a, La Rosa et al. 2002). This was despite the con- 
tinuous nutrient supply that is discharged from fish farming activity (Holby \& Hall 1991, Hall et al. 1992). Dalsgaard \& Krause-Jensen (2006), using macroalgal and phytoplankton bioassays, found high primary productivity near the fish cages, which rapidly decreased with distance from the farms. A meta-analysis of data from a large number of studies on the ecological effects of aquaculture (Sara 2007) has shown that the effect of nutrient addition on the water column in marine ecosystems is much lower than in freshwater or estuarine ecosystems. The lack of a detectable response of phytoplankton to nutrient enrichment has been attributed to the rapid dilution of nutrients, since marine sites used for fish farming are selected for their relatively strong local current regime to ensure efficient water renewal (Gowen et al. 1983).

In the present study, we investigated whether microbial grazing plays a key role in regulating phytoplankton biomass, keeping chl $a$ at very low levels and effectively transferring nutrients up the food web. These experiments were carried out using dialysis bags with and without grazer exclusions and placed in situ, downstream of fish cages.

\section{MATERIALS AND METHODS}

The phytoplankton bioassay described in Dalsgaard \& Krause-Jensen (2006) was used in the present study with a small modification to exclude grazers. Dialysis bags of $500 \mathrm{ml}$ volume (diameter $6.5 \mathrm{~cm}$, molecular weight cut-off of $6 \mathrm{kDa}$, made from Spectra Por 1 dialysis membrane) were deployed at 0, 30, 80, 200 and $500 \mathrm{~m}$ from a fish farm (1000 t annual production of sea bream and sea bass, feeding rate of ca $2000 \mathrm{t}$ of fish feed per year) in Sitia, Crete (east Mediterranean, Fig. 1) in March 2003 (Expt 1). Dissolved inorganic nitrogen concentration (DIN) near the cages was $2.8 \mu \mathrm{mol} \mathrm{\textrm {l } ^ { - 1 }}$ and dissolved inorganic phosphorus (DIP) was $0.16 \mu \mathrm{mol} \mathrm{l}^{-1}$ (Pitta et al. 2006). Sea water used for the experiment was sampled from a reference site, located $1 \mathrm{~km}$ upstream of the fish farm, at $1 \mathrm{~m}$ depth. Half of the dialysis bags were filled with $25 \mu \mathrm{m}$ filtered water to exclude large grazers such as ciliates and copepods, and the other half were filled with unfiltered water. In addition, at each distance from the nutrient discharge point, a bag containing a pure culture of Chlorella minutissima was deployed. The concentration of C. minutissima cells was adjusted so that the chl a content at the start of the experiment was similar to that of the seawater. All bags were left in the sea for $10 \mathrm{~d}$ and, after retrieval, the water was analysed for chl a content (Yentsch \& Menzel 1963). Chl a was also measured in water samples collected at the points of deployment

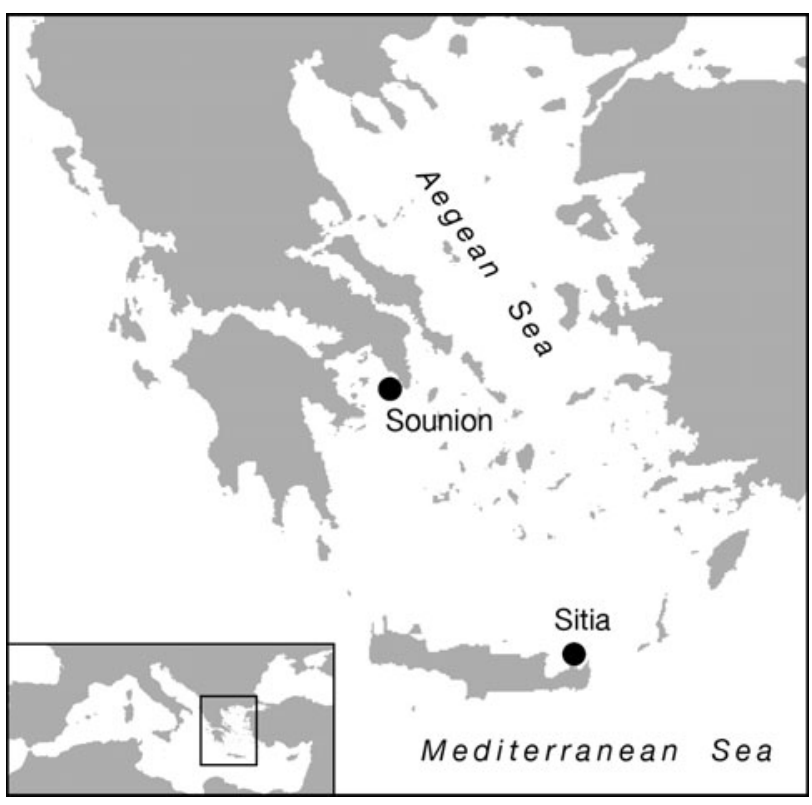

Fig. 1. Location of study sites

and at the same depth as the bags before the start and at the end of the experiment.

Expt 2 was carried out at another location (400 t annual production of sea bream and sea bass, feeding rate of ca. $800 \mathrm{t}$ of fish feed per year) in the central Aegean (Sounion, Fig. 1) in June 2004 at only 2 distances, 0 and $500 \mathrm{~m}$, from the fish cages. In this experiment, 3 replicates were used for each distance and treatment, the incubation time was $72 \mathrm{~h}$, and the water was analysed for chl a as above and for particulate organic nitrogen (PON) using a Perkin-Elmer 2400 CHN Elemental Analyzer (Hedges \& Stern 1984).

During both experiments, autotrophic nanoflagellates (ANF) were also counted. Samples (10 to $15 \mathrm{ml}$ ) were fixed with formaldehyde (final concentration $2 \%$ ), stained with 4',6-diamidino-2-phenylindole (DAPI) (Porter \& Feig 1980), filtered on $0.6 \mu \mathrm{m}$ black polycarbonate filters, and analyzed under epifluorescence microscopy using blue light.

\section{RESULTS}

\section{Expt 1: Sitia}

The bags containing filtered water as well as those containing Chlorella minutissima showed a rapid decrease in chl a content with distance from the fish farm (Fig. 2a), unlike the samples taken from all sampling stations at the start and end of the incubations (Fig. 2b) and those from the unfiltered water bags (Fig. 2a), 


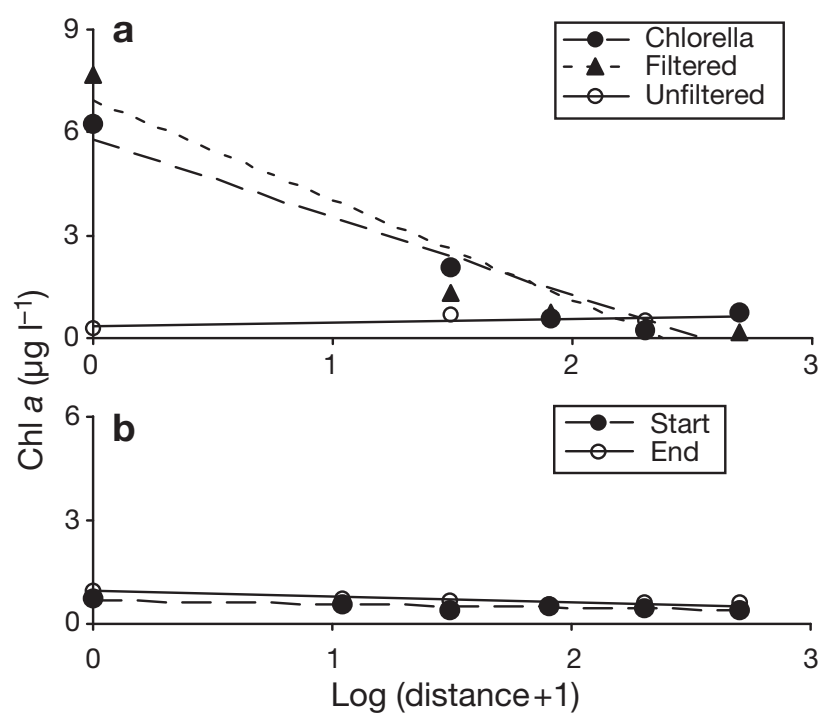

Fig. 2. Chl a levels during Expt 1. (a) In dialysis bags (incubation for $240 \mathrm{~h}$ ) with Chlorella minutissima culture, with $25 \mu \mathrm{m}$ filtered water and with unfiltered water. (b) In sea water from all sampling stations at the start and end of the incubations in (a). Trendlines fitted by MS Excel
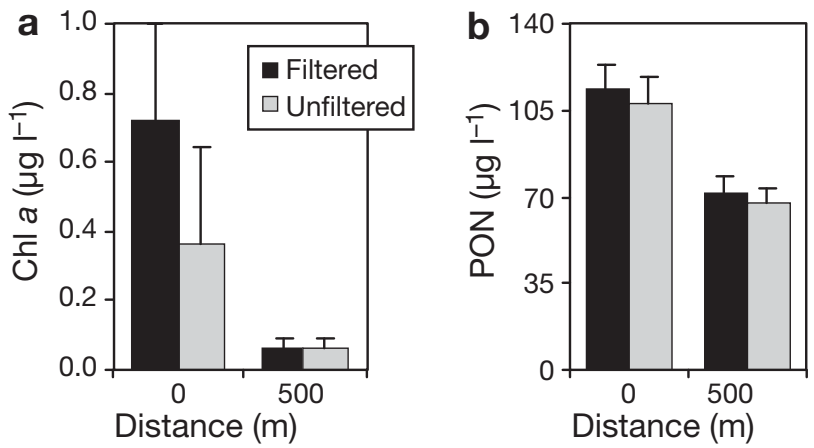

Fig. 3. Concentration (+SD) of (a) chl $a$ and (b) particulate organic nitrogen (PON) in dialysis bags during Expt 2 (incubation for $72 \mathrm{~h}$ )

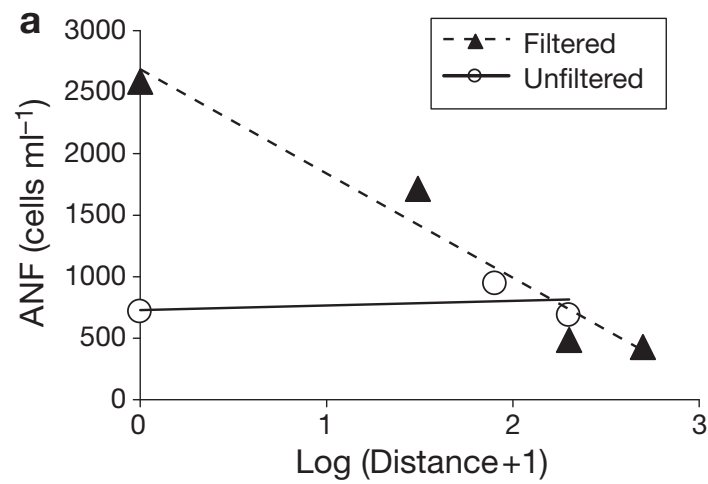

which showed very little change or no significant trend with distance and time. There was no significant difference in chl a between the bags containing filtered water and those containing $C$. minutissima (ANOVA, $\mathrm{p}>0.05$ ) at the stations close to the fish farm. After $10 \mathrm{~d}$ of incubation, the bags with unfiltered water showed no significant trend $(\mathrm{p}>0.05)$ with distance regarding their chl a content (Fig. 2a). The bag with unfiltered water deployed at the fish farm showed a chl a concentration one order of magnitude lower than the bags filled with filtered water or those containing C. minutissima (Fig. 2a).

\section{Expt 2: Sounion}

Bags with unfiltered water near the fish farm had significantly $(p<0.05)$ lower chl a concentrations after $3 \mathrm{~d}$ of deployment (Fig. 3a) than the bags filled with filtered water. In contrast to this, no significant difference ( $p>0.05$ ) was found between the bags with unfiltered and filtered water at the reference site (Fig. 3a). On the other hand, PON concentrations showed little change ( $p>0.05$ ) between the 2 treatments (bags with filtered and unfiltered water) at both sampling stations (Fig. 3b).

\section{Nanoflagellates}

ANF showed a similar trend in the experiments at both sites (Fig. 4). There was a noticeable increase in cell concentration in the bags filled with filtered water close to the fish farm at Sitia (Fig. 4a), which was 5 times higher than that in the unfiltered bags. The latter showed little change with $\log ($ distance) from the fish farm. In Expt 2 (Fig. 4b), the overall pattern in ANF concentration was similar to that of chl a.

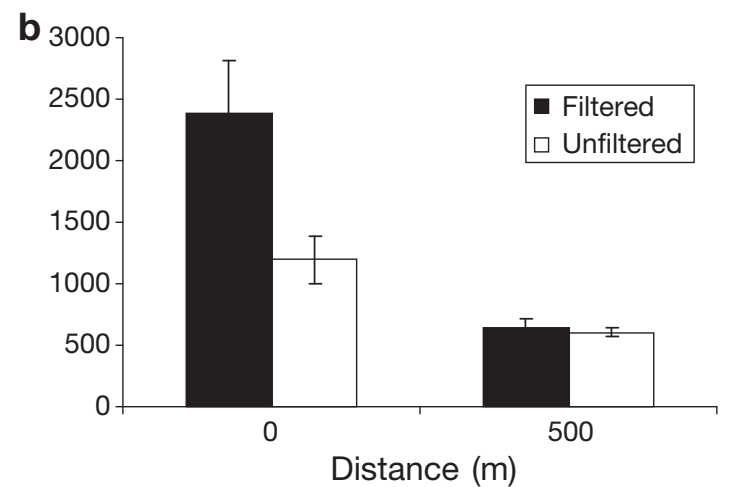

Fig. 4. Concentration of autotrophic nanoflagellates (ANF) in dialysis bags deployed during (a) Expt 1 (incubation for $240 \mathrm{~h}$ ) and (b) Expt 2 (incubation for $72 \mathrm{~h}$ ) 


\section{DISCUSSION}

The rapid decrease in phytoplankton productivity (i.e. chl a production over time) with distance from the fish farms, as seen in the experiments with filtered water and Chlorella minutissima, confirms the results of Dalsgaard \& Krause-Jensen (2006), who conducted a similar experiment at 4 Mediterranean sites along a longitudinal transect from the Spanish coast to Cyprus. However, according to the results of the present study, grazing is an important factor shaping the phytoplankton community in the extreme oligotrophic conditions of the Eastern Mediterranean, especially when nutrients are added to the environment continuously, as is the case in fish farms. This is in accordance with previous findings from freshwater environments, where the importance of predation increases with increasing productivity (Sarnelle 1992, Mazumder 1994), as well as with suggestions that top-down control of phytoplankton production also occurs in the nutrient-poor littoral waters of the NW Mediterranean (Mura et al. 1996).

In the present study, the grazers excluded from the bags containing filtered seawater were mainly ciliates; they were found to control phytoplankton biomass, as indicated by differences in both chl $a$ and ANF concentrations between bags with and without grazer exclusion. This is compatible with recent findings (Pitta et al. 2005b, Thingstad et al. 2005) of the CYCLOPS experiment during which, after an episodic P-addition in the ultraoligotrophic, phosphorus-starved eastern Mediterranean, ciliates were the only plankton group that showed a significant increase in abundance after a short period of 1 to $2 \mathrm{~d}$, due to their increased grazing on lower trophic levels favoured by the P-addition.

Ciliates are unicellular organisms (Protozoa) capable of a quick response in case of an excess food supply because they may double their populations within hours. In oligotrophic environments, phytoplankton is dominated by the pico- and nano- fractions (Caron et al. 1999), and ciliates are the main grazers, since copepods are unable to crop these size classes efficiently (Marshall 1973). Ciliates are the link between the microbial and the classical food web (Pierce \& Turner 1992), and it is reasonable to expect that they play a key role in transferring nutrients up the food web when nutrients are discharged in oligotrophic environments. In the present study, the lack of change in PON between bags with and without grazers, together with the significant changes in chl a (increased phytoplankton biomass in the absence of grazers), indicates an efficient transfer of nutrients up the food web. This could explain the increase in wild fish abundance and biomass (Machias et al. 2004, 2005, 2006) as well as the lack of increase in phytoplankton biomass (Pitta et al. 1999, 2005b, Soto \& Norambuena 2004) in areas with fish farming. The in- crease in wild fish around fish cages is usually attributed to the waste particulate matter associated with inefficiency in feeding and to the ca. $10 \%$ of the feed input being excreted as faeces by the fish (Gowen \& Bradbury 1987). In low energy systems, this forms a large pile under the cages. This probably results in a new source of food in the area, amounting to 10 to $20 \%$ of the feed supplied to the cages.

However, the discharge of waste from a fish cage is primarily in the form of dissolved nutrients (ca. $60 \%$ of the food supplied of the cages; Karakassis et al. 2005 and references therein), at least half of which are nutrients that are immediately available to phytoplankton. Our results suggest that these nutrients are rapidly taken up into the microbial food chain and from there up to larger organisms. This is a greater input than the waste particulate matter, and therefore a more important resource for wild fish around such fish cages. This is again compatible with the findings of Machias et al. $(2004,2005,2006)$, who found an increase in biomass also of fish species other than those usually aggregating beneath fish farms in the Mediterranean (Dempster et al. 2002).

In other words, when nutrients are discharged in oligotrophic environments, either in pulses or continuously, there is a quick transfer via the grazing food chain towards higher trophic levels. In the case of the pulsed P-addition of the Lagrangian experiment in the Eastern Mediterranean, an increase in the ciliate community (Pitta et al. 2005b), as well as an increase in copepod egg production (Pasternak et al. 2005), was seen after 1 to $2 \mathrm{~d}$. It is unknown at which trophic level the pulsed P-addition of the Langrangian experiment ended up when the system returned to steady state. On the other hand, in the case of continuous nutrient addition by fish farms, it seems that the biomass increase reaches the top predators (Machias et al. 2004, 2005), resulting in a significant increase in fisheries production (Machias et al. 2006). Further research is needed in order to find out whether the mechanism is exactly the same in both cases.

The difference in magnitude of the response between the 2 experiments (Sitia and Sounion) is probably due to the difference in incubation time, since population growth of grazers lags in comparison to that of the autotrophic plankton. Comparative experiments with nutrient addition in mesocosms within the framework of the COMWEB project (Comparative analysis of food webs based on flow networks; Olsen et al. 2001, 2006) showed that the nutrients added to Mediterranean, Baltic and Norwegian coastal mesocosms were effectively removed from the water via photosynthesis, but only in the case of the Mediterranean experiment did the autotrophic biomass not accumulate. Olsen et al. (2006) provided several explanations for this Mediter- 
ranean peculiarity, such as a high phytoplankton lysis rate (Agusti \& Duarte 2000) or efficient grazing by mesozooplankton (mainly dominated by doliolids in their experiment). The initial dominance of doliolids was considered by Olsen et al. (2006) as a potential source of deviation from the conditions representative of the Mediterranean. In our experiments, the overall lack of accumulation of autotrophic biomass in the unfiltered bags is compatible with the COMWEB results for the Mediterranean presented by Olsen et al. (2001, 2006). However, it is very unlikely that, in the present study, mesozooplankton cropped the autrophic biomass, due to the small volume included in the bags. The phytoplankton lysis rate cannot be used as an explanation, as can be seen in the case of filtered bags, which showed a conspicuous increase of autotrophs close to the nutrient source.

The overall conclusion of the present study is that the lack of response of phytoplankton abundance to nutrient addition from fish farms is mainly due to grazing by microzooplankton, which plays a key role in transferring nutrients up the food web. If our conclusions are generally applicable, then it should be asked why eutrophication occurs in many marine ecosystems in response to nutrient addition. Ciliates are found everywhere and therefore they could efficiently graze the water column nanoplankton, thereby inhibiting phytoplankton blooms in any marine area. The fact that this type of response has been found only in oligotrophic conditions is probably due to the different structure of the phytoplankton community in such areas, i.e. based on small cell-size primary producers (Caron et al. 1999). These can be easily grazed by ciliates, whereas in mesotrophic or eutrophic areas and in water bodies receiving high Si input there is a chance that large cellsize primary producers (diatoms, dinoflagellates) will prevail. In the latter case, primarily copepods or other planktonic metazoans will be able to harvest the produced surplus phytoplankton biomass, and this cannot be achieved as rapidly as in the case of ciliates, due to the metazoans' longer life cycles.

Acknowledgements. The authors acknowledge support by the European Commission (Project MEDVEG, Contract: EUDG XIV: QLRT 2000-02456). Thanks to T. Dalsgaard for technical advice with the bioassays, I. Glabedakis for assistance with sampling and S. Zivanovic and E. Dafnomili for their assistance during chemical analyses. Thanks are due to 4 anonymous reviewers for their comments and suggestions, which greatly helped in improving the manuscript.

\section{LITERATURE CITED}

Agusti S, Duarte CM (2000) Strong seasonality in phytoplankton celllysis in the NW Mediterranean littoral. Limnol Oceanogr 45:940-947

Caron DA, Peele ER, Lim EL, Dennett MR (1999) Picoplank- ton and nanoplankton and their trophic coupling in surface waters of the Sargasso Sea south of Bermuda. Limnol Oceanogr 44:259-272

> Dalsgaard T, Krause-Jensen D (2006) Monitoring nutrient release from fish farms with macroalgal and phytoplankton bioassays. Aquaculture 256:302-310

> Dempster T, Sanchez-Jerez P, Bayle-Sempere JT, GiménezCasalduero F, Valle C (2002) Attraction of wild fish to seacage fish farms in the south-western Mediterranean Sea: spatial and short-term temporal variability. Mar Ecol Prog Ser 242:237-252

Gowen RJ, Bradbury NB (1987) The ecological impact of salmonid farming in coastal waters: a review. Oceanogr Mar Biol Annu Rev 25:563-575

Gowen RJ, Tett P, Jones KJ (1983) The hydrography and phytoplankton ecology of Loch Ardbhair: a small sea loch on the West Coast of Scotland. J Exp Mar Biol Ecol 71: $1-16$

Hall POJ, Holby O, Kollberg S, Samuelsson MO (1992) Chemical fluxes and mass balances in a marine fish cage farm. IV. Nitrogen. Mar Ecol Prog Ser 89:81-91

Hedges JI, Stern JH (1984) Carbon and nitrogen determination of carbonate containing solids. Limnol Oceanogr 29: $657-663$

Holby O, Hall POJ (1991) Chemical fluxes and mass balances in a marine fish cage farm. II. Phosphorus. Mar Ecol Prog Ser 70:263-272

Karakassis I, Pitta P, Krom MD (2005) Contribution of fish farming to the nutrient loading of the Mediterranean. Sci Mar 69:313-321

Krom MD, Kress N, Brenner S, Gordon LI (1991) Phosphorus limitation of primary productivity in the eastern Mediterranean Sea. Limnol Oceanogr 36:424-432

Krom MD, Thingstad TF, Brenner S, Carbo P and others (2005) Summary and overview of the CYCLOPS P addition Lagrangian experiment in the Eastern Mediterranean. Deep-Sea Res II 52:3090-3108

La Rosa T, Mirto S, Favaloro E, Savona B, Sara G, Danovaro R, Mazzola A (2002) Impact on the water column biogeochemistry of a Mediterranean mussel and fish farm. Water Res 36:713-721

Machias A, Karakassis I, Labropoulou M, Somarakis S, Papadopoulou KN, Papaconstantinou C (2004) Changes in wild fish assemblages after the establishment of a fish farming zone in an oligotrophic marine ecosystem. Estuar Coast Shelf Sci 60:771-779

Machias A, Karakassis I, Giannoulaki M, Papadopoulou KN, Smith CJ, Somarakis S (2005) Response of demersal fish communities to the presence of fish farms. Mar Ecol Prog Ser 288:241-250

Machias A, Giannoulaki M, Somarakis S, Maravelias CD, Neofitou C, Koutsoubas D, Papadopoulou KN, Karakassis I (2006) Fish farming effects on local fisheries landings in oligotrophic seas. Aquaculture 261:809-816

> Marshall SM (1973) Respiration and feeding in copepods. Adv Mar Biol 11:57-120

> Mazumder A (1994) Patterns of algal biomass in dominant odd-link vs. even-link lake ecosystems. Ecology 75: $1141-1149$

Mura MP, Agusti S, del Giorgio, PA, Gasol JM, Vaque D, Duarte CM (1996) Loss-controlled phytoplankton production in nutrient-poor littoral waters of the NW Mediterranean: in situ experimental evidence. Mar Ecol Prog Ser 130:213-219

Olsen Y, Reinertsen H, Vadstein $O$, Andersen $\mathrm{T}$ and others (2001) Comparative analysis of food webs based on flow networks: effects of nutrient supply on structure and func- 
tion of coastal plankton communities. Continental Shelf Res 21:2043-2053

Olsen Y, Agusti S, Andersen T, Duarte CM and others (2006) A comparative study of responses in planktonic food web structure and function in contrasting European coastal waters exposed to experimental nutrient addition. Limnol Oceanogr 51:488-503

Pasternak A, Wassmann P, Wexels Riser C (2005) Does mesozooplankton respond to episodic P inputs in the Eastern Mediterranean? Deep-Sea Res II 52:2975-2989

Pierce RW, Turner JT (1992) Ecology of planktonic ciliates in marine food webs. Rev Aquat Sci 6:139-181

Pitta P, Karakassis I, Tsapakis M, Zivanovic S (1999) Natural vs. mariculture induced variability in nutrients and plankton in the Eastern Mediterranean. Hydrobiologia 391: 181-194

Pitta P, Apostolaki ET, Giannoulaki M, Karakassis I (2005a) Mesoscale changes in the water column in response to fish farming zones in three coastal areas in the Eastern Mediterranean Sea. Estuar Coast Shelf Sci 65:501-512

Pitta P, Stambler N, Tanaka T, Zohary T, Tselepides A, Rassoulzadegan F (2005b) Biological response to P addition in the Eastern Mediterranean Sea. The microbial race

Editorial responsibility: Katherine Richardson, Copenhagen, Denmark against time. Deep-Sea Res II 52:2961-2974

> Pitta P, Apostolaki ET, Tsagaraki T, Tsapakis M, Karakassis I (2006) Fish farming effects on chemical and microbial variables of the water column: a spatio-temporal study along the Mediterranean Sea. Hydrobiologia 563:99-108

Porter KG, Feig YS (1980) The use of DAPI for identifying and counting aquatic microflora. Limnol Oceanogr 25:943-948

Sara G (2007) A meta-analysis on the ecological effects of aquaculture on the water column: dissolved nutrients. Mar Environ Res 63:390-408

Sarnelle O (1992) Nutrient enrichment and grazer effects on phytoplankton in lakes. Ecology 73:551-560

Soto D, Norambuena F (2004) Evaluation of salmon farming effects on marine systems in the inner seas of southern Chile: a large-scale mensurative experiment. J Appl Ichtyol 20:493-501

Thingstad TF, Krom MD, Mantoura RFC, Flaten GAF and others (2005) Nature of phosphorus limitation in the ultraoligotrophic eastern Mediterranean. Science 309: 1068-1071

Yentsch CS, Menzel DW (1963) A method for the determination of phytoplankton chlorophyll and phaeophytin by fluorescence. Deep-Sea Res 10:221-231

Submitted: February 11, 2008; Accepted: September 30, 2008 Proofs received from author(s): December 1, 2008 